MATEC Web of Conferences 9, 03003 (2013)

DOI: $10.1051 /$ matecconf/20130903003

(C) Owned by the authors, published by EDP Sciences, 2013

\title{
Comparative assessment of CFD Tools and the Eurocode Methodology in describing Externally Venting Flames
}

\author{
Eleni K. Asimakopoulou a, Dionysios I. Kolaitis and Maria A. Founti \\ Laboratory of Heterogeneous Mixtures and Combustion Systems, Thermal Engineering \\ Section, School of Mechanical Engineering, National Technical University of Athens 9 Heroon \\ Polytechneiou St., Polytechneioupoli Zografou, Athens 15780, Greece
}

\begin{abstract}
The ability of currently available Computational Fluid Dynamics (CFD) tools to adequately describe Externally Venting Flames (EVF) is assessed, aiming to demonstrate compliance with performance-based fire safety regulations. The Fire Dynamics Simulator (FDS) CFD tool is used to simulate the EVF characteristics in a corridor-compartment-façade configuration exposed to natural fire conditions. Numerical results of the temporal evolution of gas velocity, gas temperatures and flame shape are obtained for both the interior and the exterior of the compartment. Predictions are compared to respective experimental data, as well as to correlations suggested by the Eurocode methodology. The effects of ventilation conditions are investigated by simulating both Forced Draught (FD) and No Forced Draught (NoFD) test cases. The obtained results suggest that currently available CFD tools are capable of achieving good qualitative agreement with experimental data and, in certain cases (e.g. FD conditions), adequate quantitative agreement, that generally outperforms the Eurocode prescriptive methodology.
\end{abstract}

\section{INTRODUCTION}

In a fully developed, under-ventilated compartment fire, flames may spill out of external openings (e.g. windows), should the glazing fail. Externally Venting Flames (EVF) may pose a significant risk of fire spreading to adjacent floors or buildings, especially nowadays when there is an ever-increasing trend of using combustible materials in building façades for energy performance purposes. However, most fire safety codes are lacking specific methodologies to evaluate the risks associated with EVF. In this context, the Eurocode design guidelines [1], recently implemented in the European Union (E.U.), contain a set of comprehensive correlations, focusing on the protection of steel and timber elements from EVF.

Historically, fire protection systems in buildings have been commonly regulated using "prescriptive" codes and methodologies. Today, there is a growing worldwide trend towards implementing modern "performance-based" codes, which offer a range of advantages. The implementation of performancebased codes requires the use of advanced simulation tools, such as Computational Fluid Dynamics (CFD) codes. CFD tools can provide a wealth of information regarding the detailed characteristics of the flow- and thermal-field developing inside or outside the compartment; as a result, the thermal impact of EVF on the façade elements can be thoroughly assessed. Despite this fact, there are few numerical simulation studies available that focus on EVF and relevant façade fire safety issues [2-5]. Until now, emphasis was given mainly on the study of fire behaviour inside compartments and the effect of the various ventilation parameters on the fire environment, e.g. [6, 7], and not on the effects of fire spreading and smoke propagation beyond the compartment of origin. The main scope of the present study is to

\footnotetext{
ae-mail: elasimak@mail.ntua.gr
}

This is an Open Access article distributed under the terms of the Creative Commons Attribution License 2.0, which permits unrestricted use, distribution, and reproduction in any medium, provided the original work is properly cited. 


\section{MATEC Web of Conferences}

assess the ability of currently available CFD tools to adequately describe the EVF characteristics, with the aim of demonstrating compliance with performance-based fire safety regulations. In this context, a CFD tool is used to simulate a real scale compartment-façade configuration exposed to natural fire conditions. The obtained predictions are compared to available experimental data, as well as to values using the relevant correlations proposed in the Eurocodes. EFV characteristics are mainly determined by opening geometry, ventilation conditions, fuel load and building material properties [8]. In this context, the effect of ventilation conditions is investigated by performing a parametric study for both Forced Draught (FD) and No Forced Draught (NoFD) conditions.

\section{EUROPEAN FIRE SAFETY LEGISLATION}

Building codes and regulations include methods and measures in order to ensure maximum safety against fire events. In the E.U., the structural Eurocodes in combination with each member state's regulations are applied in order to determine a wide range of analytical procedures and design rules concerning the construction of structures; in this context, a set of minimum requirements for the design and construction of buildings is proposed.

\subsection{The Eurocode methodology}

The structural Eurocodes form a set of documents that determine the imposed actions in order to assist the structural design of buildings. The design procedure for a building includes methods for describing the behaviour of the structure at elevated temperatures, its potential heat exposure and the effects of active or/and passive fire protection systems. Actions for designing load bearing structures are prescribed in EN 1991, Eurocode 1 (EC1) [1]. More specifically, Part 1-2 of EN 1991 gives general principles and application rules regarding the thermal and mechanical actions on structures exposed to fire. There are two ways of demonstrating compliance with EC1, either following the prescriptive or the performance-based approach. The prescriptive approach uses nominal fires to generate thermal actions and indicates a set of simple rules for the design and verification of structural elements. This method is valid for fire loads higher than $200 \mathrm{MJ} / \mathrm{m}^{2}$, near rectangular enclosures, floor areas less than $500 \mathrm{~m}^{2}$, heights less than $4 \mathrm{~m}$, no ceiling openings and time dependent thermal properties for façade elements. The performance-based approach (as prescribed in Annex D of the EC1), using fire safety engineering techniques, such as zone or CFD models, refers to thermal actions based on physical and chemical parameters. However, no particular guidance is given by the EC1 on the actual set up of such a case, thus leaving the identification of the means to demonstrate compliance to the engineer.

\subsection{Eurocode prescriptive methodology}

The prescriptive method described in Annex B of the EC1 "Thermal actions of external members", allows the calculation of the maximum temperatures inside the fire compartment, the geometry and temperature profile of the EVF and the relevant convection and radiation parameters. The effects of wind, ventilation conditions and existence of balconies in the EVF's characteristics are also taken into account. If there are windows on opposite sides of the compartment or air flow from another source, then Forced Draught (FD) conditions apply. Otherwise, No Forced Draught (NoFD) conditions are used for the calculations. The EVF temperature along the centerline axis is given by Eq. (1) and (2), for the FD and NoFD ventilation conditions, respectively.

$$
T_{z}=\left(T_{w}-T_{o}\right)\left(1-0.3325\left(L_{x} \frac{\sqrt{A_{v}}}{Q}\right)\right)+T_{o} \text { with } L_{f} \frac{\sqrt{A_{v}}}{Q}<1
$$




$$
T_{z}=\left(T_{w}-T_{o}\right)\left(1-0.4725\left(L_{x} \frac{w_{t}}{Q}\right)\right)+T_{o} \text { with } L_{f} \frac{w_{t}}{Q}<1
$$

$L_{x}$ corresponds to the axis length from the window to the point where the calculation is made and $T_{w}$ is the flame temperature at the window, calculated using Eqs. (3) and (4), for FD and NoFD conditions, respectively. The temperature at the window of the compartment depends on the window area $\left(A_{v}\right)$, window width $\left(w_{t}\right)$, flame length $\left(L_{f}\right)$ and rate of heat release $(Q)$.

$$
\begin{gathered}
T_{w}=\frac{520}{\left(1-0.3325\left(L_{f} \frac{\sqrt{A_{v}}}{Q}\right)\right)}+T_{o} \text { with } L_{f} \frac{\sqrt{A_{v}}}{Q}<1 \\
T_{w}=\frac{520}{\left(1-0.4725\left(L_{f} \frac{w_{t}}{Q}\right)\right)}+T_{o} \text { with } L_{f} \frac{w_{t}}{Q}<1 .
\end{gathered}
$$

The overall height $\left(L_{L}\right)$ and width $\left(L_{H}\right)$. othe EVF depends mainly on the rate of heat release of the fire, the weighted average of window heights on all walls $\left(h_{e q}\right)$, the total area of vertical openings on all walls $\left(A_{v}\right)$ and the wind speed $(u)$. In case of a wall located above the window (façade), values for the $L_{L}$ and $L_{H}$ of the EVF are calculated using Eqs. (5) and (6) for FD conditions and Eqs. (7) and (8)-(10) for NoFD conditions; $w_{t}$ corresponds to the sum of window widths on all walls of the burn room.

$$
\begin{gathered}
L_{L}=\left(1.366\left(\frac{1}{u}\right)^{0.43} \frac{Q}{A_{v}^{1 / 2}}\right)-h_{e q} \\
L_{H}=0.605\left(\frac{u^{2}}{h_{e q}}\right)^{0.22}\left(L_{L}+h_{e q}\right) \\
L_{L}=\max \left\{0 ; h_{e q}\left(2.37\left(\frac{Q}{A_{v} \rho_{g}\left(h_{e q}\right)^{1 / 2}}\right)^{2 / 3}-1\right)\right\} \\
L_{H}=\frac{h_{e q}}{3} \text { if } h_{e q} \leq 1.25 w_{t} \\
L_{H}=0.3 h_{e q}\left(\frac{h_{e q}}{w_{t}}\right)^{0.54}, \quad \text { if } h_{e q}>1.25 w_{t} \text { and distance to any other window }>4 w_{t} \\
L_{H}=0.454 h_{e q}\left(\frac{h_{e q}}{2 w_{t}}\right)^{0.54} \text { in any other case. }
\end{gathered}
$$

\section{TEST CASES DESCRIPTION}

Aiming to investigate the effect of ventilation conditions to the development of an EVF from a fire compartment, a set of relevant experimental results was selected from the literature ([8,9]). Two different experimental layouts have been chosen, as shown in Figure 1, representing NoFD and FD ventilation conditions. The NoFD test case constitutes of a fire compartment-façade configuration, measuring $5.3 \mathrm{~m} \times 3.6 \mathrm{~m} \times 2.4 \mathrm{~m}$ (compartment) and $3.6 \mathrm{~m} \times 7.5 \mathrm{~m}$ (facade) respectively, with a $2.4 \mathrm{~m} \times 1.5 \mathrm{~m}$ single opening (W102) placed at the center of the southern fire compartment wall, $0.5 \mathrm{~m}$ above the floor. The fire compartment and façade were lined with 2 layers of $16 \mathrm{~mm}$ fire rated plasterboards. In the FD test case, the same fire compartment is located next to a corridor, which allows 


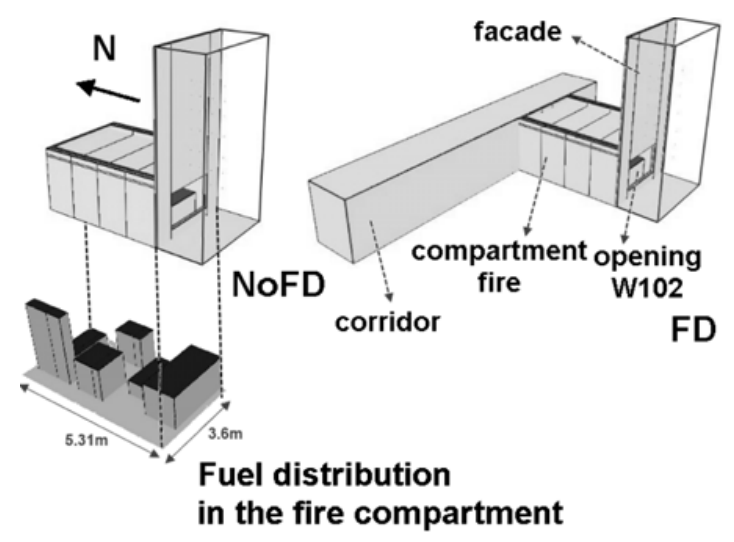

Figure 1. General configuration and fuel distribution in the fire compartment for the NoFD (left) and FD (right) test cases.

air flow through the compartment through a door, measuring, $0.8 \mathrm{~m} \times 2.0 \mathrm{~m}$ and located at the center of the northern wall.

In both test cases, the fuel distribution was selected to mimic a typical residential environment, constituting of one three-seater couch with its back facing the window, two coffee tables, two single seaters, bookshelves and a carpet. An extensive set of measurements, i.e. mass loss rate, indoor and outdoor temperature, velocity and heat flux distributions, were available for the NoFD and FD test cases [9], providing a detailed description of the fire compartment conditions and the developing EVF.

\section{NUMERICAL SIMULATIONS}

\subsection{Description of the CFD code}

The implementation of the performance-based methodology was carried out using the Fire Dynamics Simulator (FDS) CFD tool for the numerical simulation of the EVF development for the NoFD and FD test cases. Turbulence is described by using the Large Eddy Simulation (LES) approach; the subgridscale turbulence is simulated using the Smagorinsky model, utilizing a Smagorinsky constant $\left(C_{S}\right)$ value of 0.2. Thermal radiation is simulated using the finite volume methodology on the same grid as the flow solver; 100 radiation angles are used.

\subsection{Simulation details}

Predictions of CFD codes using the LES approach are known to significantly depend on the size of the numerical grid [10]. In the general context of compartment fire simulations, the quality of the utilized grid resolution is commonly assessed using the non-dimensional $D^{*} / \delta x$ ratio, where $D^{*}$ is a characteristic fire diameter and $\delta x$ corresponds to the nominal size of the grid cell. The $D^{*} / \delta x$ ratio corresponds to the number of computational cells spanning $D^{*}$ and is representative of the adequacy of the grid resolution. If the value of the $D^{*} / \delta x$ ratio is sufficiently large, the fire can be considered well resolved. Several studies have shown that values of 10 or more are required to adequately resolve most fires and obtain reliable flame temperatures $([11,12])$. In the current study, aiming to fulfill the $D^{*} / \delta x>10$ criterion and, at the same time, reduce the required computational cost, a $0.075 \mathrm{~m}$ cell size was selected for the entire domain, except from the corridor (in the FD test case) where a $0.15 \mathrm{~m}$ cell size was used. The numerical grid extends to the outside of the fire compartment-façade configuration, in order to effectively simulate air entrainment phenomena [13]. Relevant numerical parameters and 
$1^{\text {st }}$ International Seminar for Fire Safety of Facades, Paris (France), 2013

Table 1. Main parameters and initial conditions for the NoFD and FD test cases.

\begin{tabular}{cccc}
\hline \multirow{2}{*}{ Parameter } & \multirow{2}{*}{ Unit } & \multicolumn{2}{c}{ Test Case } \\
\cline { 3 - 4 } & & NoFD & FD \\
\hline Corridor-Fire compartment door & & Closed & Open \\
Opening W102 & & Open & Open \\
Total number of computational cells & & 285,768 & 314,928 \\
Total simulation time & $(\mathrm{s})$ & 1900 & 1900 \\
Wood equivalent fuel load & $\left(\mathrm{kg} / \mathrm{m}^{2}\right)$ & 28.32 & 26.36 \\
Ambient temperature & $\left({ }^{\circ} \mathrm{C}\right)$ & 11 & 15.4 \\
Wind speed & $(\mathrm{m} / \mathrm{s})$ & 1.6 & 1.5 \\
Wind direction & & $\mathrm{NE}$ & $\mathrm{NE}$ \\
\hline
\end{tabular}
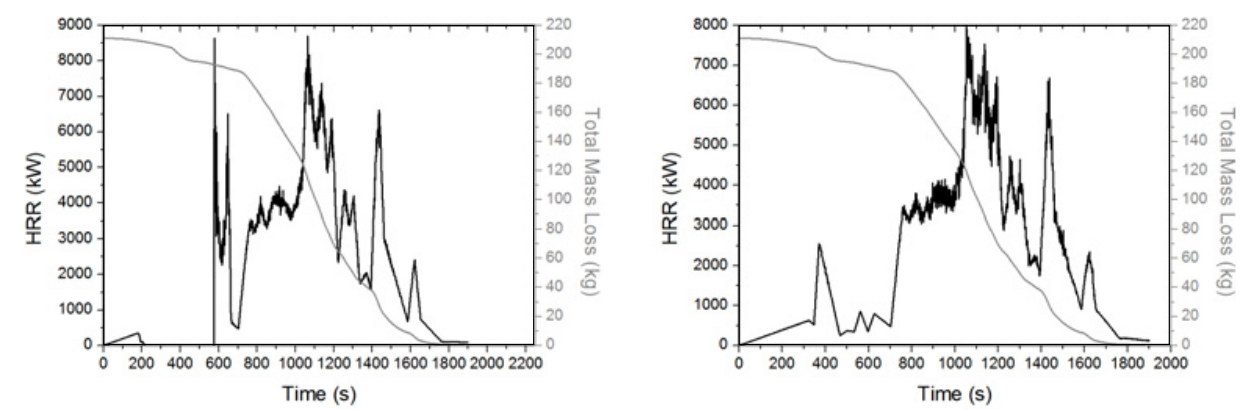

Figure 2. Temporal evolution of HRR and total mass loss of the fuel load, for the NoFD (left) and FD (right) test cases [8].

initial conditions used for NoFD and FD test cases are shown in Table 1. Open boundary conditions are imposed to all external boundaries. Measured values of the temporal evolution of HRR are taken into account (Fig. 2). The use of realistic fire temperature curves in performance-based methodologies is known to increase the accuracy in the description of the actual fire performance of the structure [14]. In contrast, prescriptive codes are based on the use of nominal fire temperature curves to describe a uniform fire load inside the fire compartment.

\subsection{Numerical results}

Predictions of the gas mixture temperature during the fully developed phase, approximately $1000 \mathrm{~s}$ after fire initiation, are depicted in Figure 3, for both test cases. In the NoFD test case, the fire is sustained only by the air supply through the window, causing the flames to vent from the upper part of the window, while air is drawn in from its lower part. The effect of ventilation conditions is evident, since the upper hot gas layer inside the burn room in that case is considerably higher. On the other hand, in the FD case, it is evident that the additional air flow from the corridor through the door allows the flames to vent from almost the entire window opening area, resulting in considerable larger volume of unburned gases venting in the exterior domain, forming larger EVF and a stronger buoyant plume flow.

Most research efforts and relevant empirical correlations for the estimation of flame trajectory and EVF geometric characteristics were developed on the basis that the locus of the visible flame tip corresponds approximately to $540{ }^{\circ} \mathrm{C}([15,16])$. Assuming that this temperature is the minimum flame temperature, predictions of the EVF location and shape for the NoFD and FD test cases are illustrated in Figure 4. As the fire progresses in the NoFD test case, the upper layer descends and a larger portion of fuel-rich gases is ejected from the upper layer of the window, mixing with ambient (oxygen rich) air. 


\section{MATEC Web of Conferences}
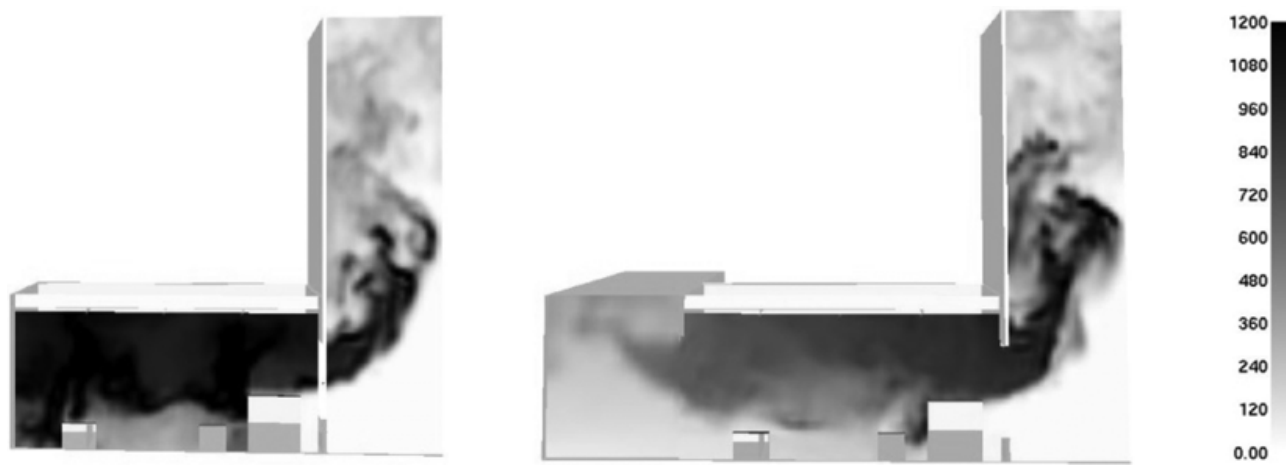

Figure 3. Predictions of gas mixture temperature $\left({ }^{\circ} \mathrm{C}\right), 1000 \mathrm{~s}$ after fire initiation, for test case NoFD (left) and FD (right).
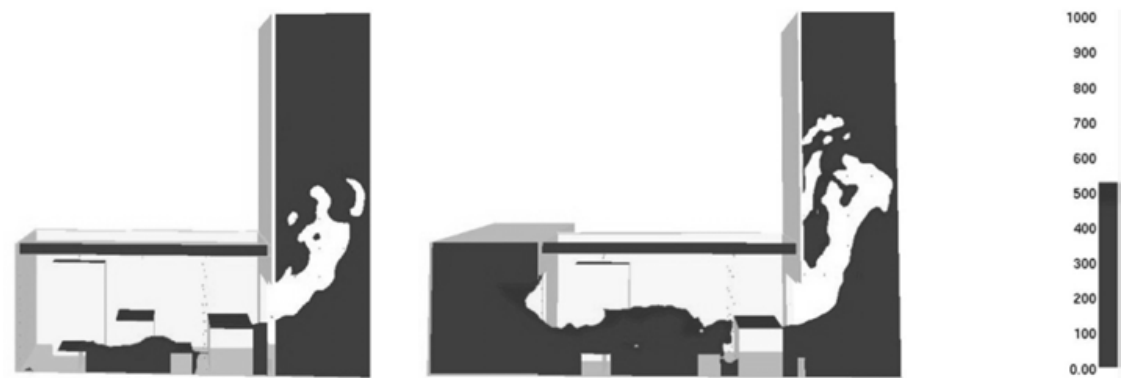

Figure 4. Predictions of EVF shape and location, $1000 \mathrm{~s}$ after fire initiation, for test case NoFD (left) and FD (right).

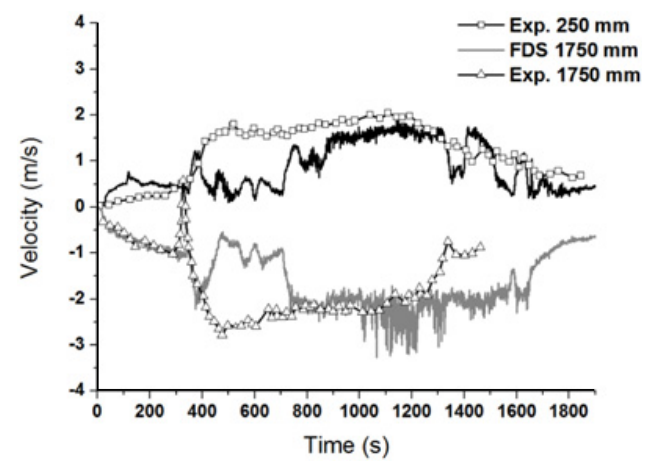

Figure 5. Velocity histories at the centre of the fire compartment door, at $250 \mathrm{~mm}$ and $1750 \mathrm{~mm}$ heights (FD test case).

In the FD test case, the open door in the northern wall creates a bi-directional flow in the fire compartment. Temperature stratification results in hot gases exiting not only through the window, as in the NoFD test case, but also through the upper part of the door. Predictions of velocities at the centre of the fire compartment's door, at a height of $250 \mathrm{~mm}$ and $1750 \mathrm{~mm}$ above the floor level, are plotted in Figure 5 against experimental data for the FD case. Negative values imply gas flowing out of the fire compartment. In general, very good quantitative agreement is observed, especially after the first 


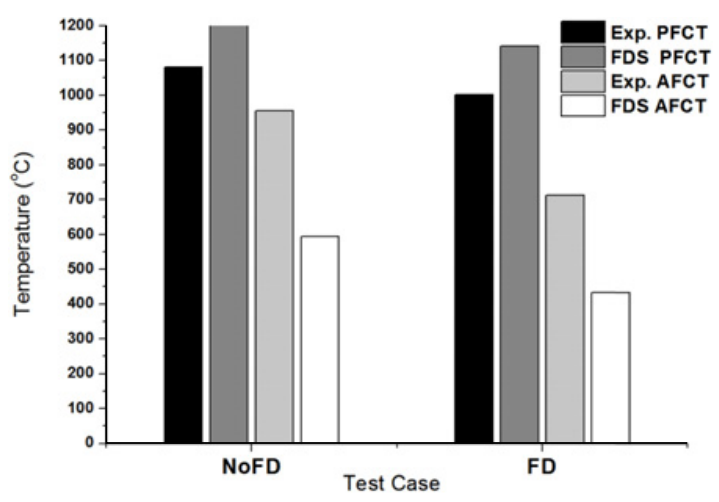

Figure 6. Peak Fire Compartment Temperatures (PFCT) and Average Fire Compartment Temperatures (AFCT) for the NoFD (left) and FD (right) test cases.

$800 \mathrm{~s}$. At the lower layer of the door ( $250 \mathrm{~mm}$ height), FDS generally over-predicts the measured values, whereas at the upper layer $(1750 \mathrm{~mm}$ height) there is an overall slight under-prediction.

Predictions of the peak and average temperatures obtained at the interior of the fire compartment are compared to respective experimental data in Figure 6. Both Peak Fire Compartment Temperature (PFCT) and Average Fire Compartment Temperature (AFCT) reach higher values in the NoFD test case, compared to the FD test case. In both cases, the PFCT values are overestimated by FDS by a factor of $10-15 \%$, which is considered to be an acceptable level [17]. However, this is not the case for the AFCT values, where predictions significantly underestimate experimental data by $35-40 \%$. This behaviour may be attributed to the difficulty of the FDS code to accurately predict gas temperatures in under-ventilated fire conditions [18], pertaining to both the examined test cases.

Measurements and predictions of average temperature contours on a reference plane, lying tangent to the façade and collinear to the centerline of the window W102, are depicted in Figure 7. The presented values are normalized using the respective maximum external temperature value. Good levels of qualitative and quantitative agreement are generally observed. In the NoFD test case, the flames vent away from the opening but stay attached to the façade wall, whereas in the FD test case the EVF tilts away from the facade. Predictions accurately depict the average EVF temperature distribution for the NoFD case, though the flame attachment to the façade wall is not clearly depicted. In the FD test case, FDS tends to under-predict the measured values; nevertheless the general tilting trend of the EVF is properly captured.

The effect of ventilation conditions on the predicted temperatures at the façade wall is evident in Figure 8. As expected, the façade wall is directly exposed to a more intense EVF plume in the FD case, thus exhibiting higher temperature gradients. In the NoFD test case, the larger portion of combustion takes place in the interior of the fire compartment, thus resulting in a less intensified ECF plume that drifts further away from the façade and, therefore, exhibiting a reduced impact on the façade wall's temperature.

\section{CFD VS. EUROCODE}

\subsection{Centreline temperature}

Numerical predictions of the EVF centerline temperatures are compared to both experimental data and relevant Eurocode correlations (Eqs. (1)-(10)) in an attempt to evaluate the applicability and effectiveness of each method in both NoFD and FD conditions. The fire load density value required in the Eurocode methodology corresponds to the specific experimental conditions [8]; the used 


\section{MATEC Web of Conferences}
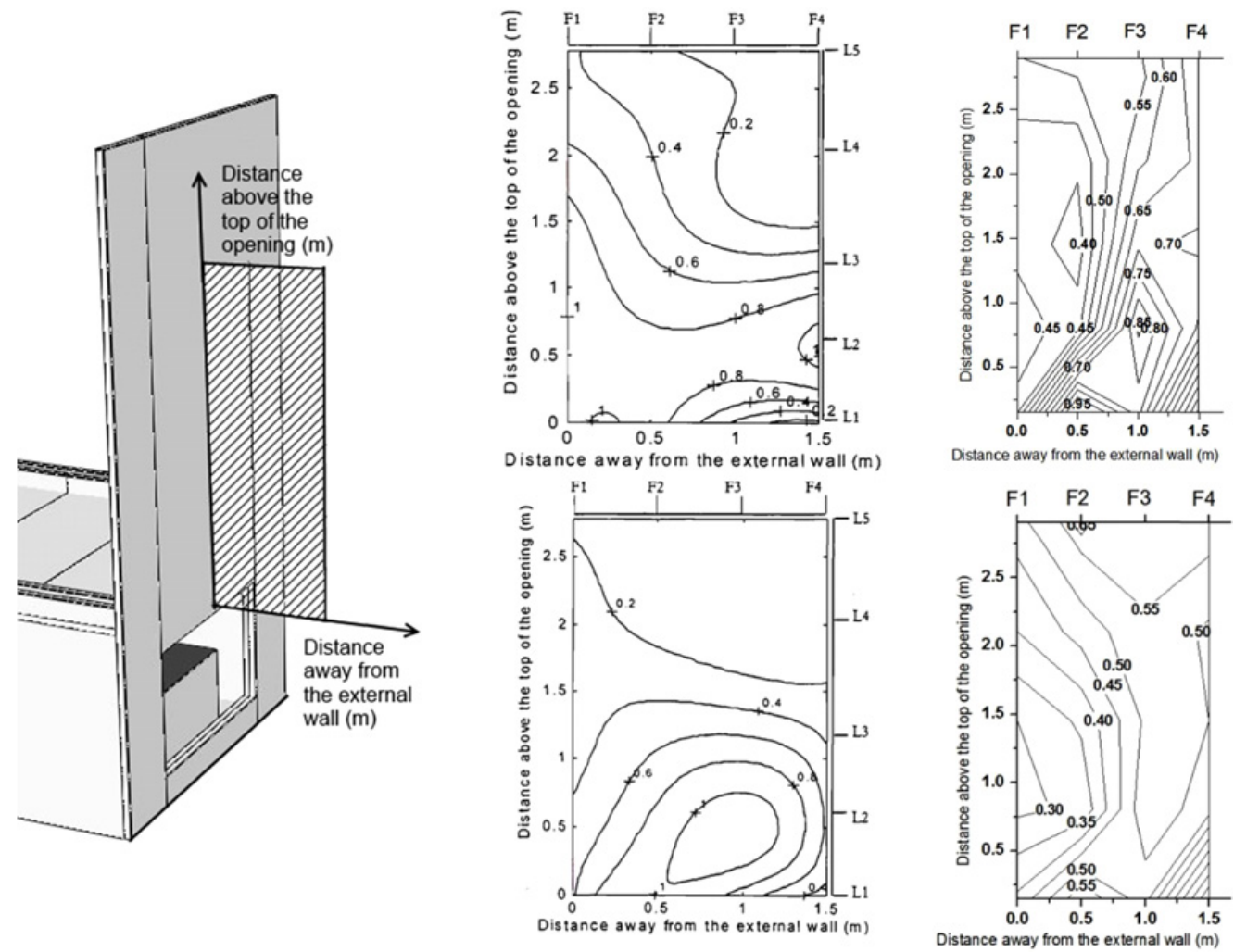

Figure 7. Normalized temperature spatial distribution; measurements (left) and FDS predictions (right) for the NoFD (top) and FD (bottom) test cases.
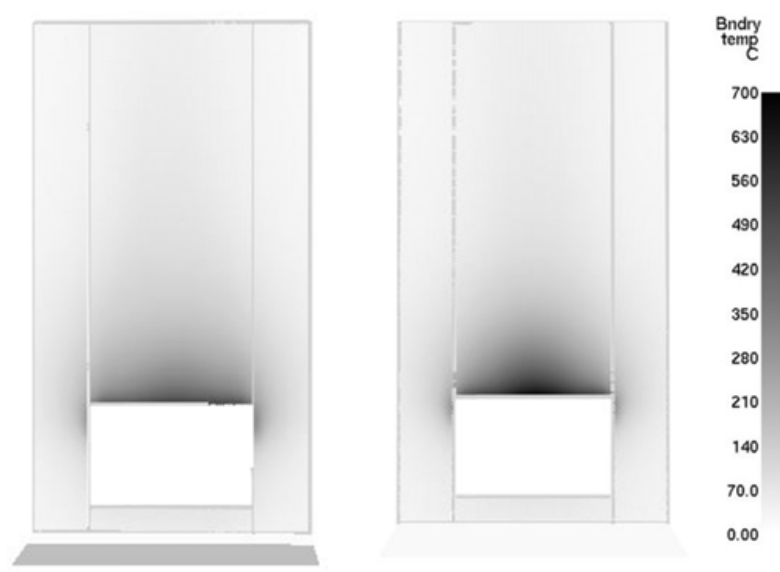

Figure 8. Predictions of facade wall temperature, $1000 \mathrm{~s}$ after fire initiation, for test cases NoFD (left) and FD (right).

$544.12 \mathrm{MJ} / \mathrm{m}^{2}$ value is a fair approximation of the $80 \%$ fractile Eurocode classification for office occupancy, $511 \mathrm{MJ} / \mathrm{m}^{2}[1]$. The measured $([8,9])$ and predicted EVF centerline values are essentially time-averaged values, over the duration of the experimentally observed Consistent External Flaming 

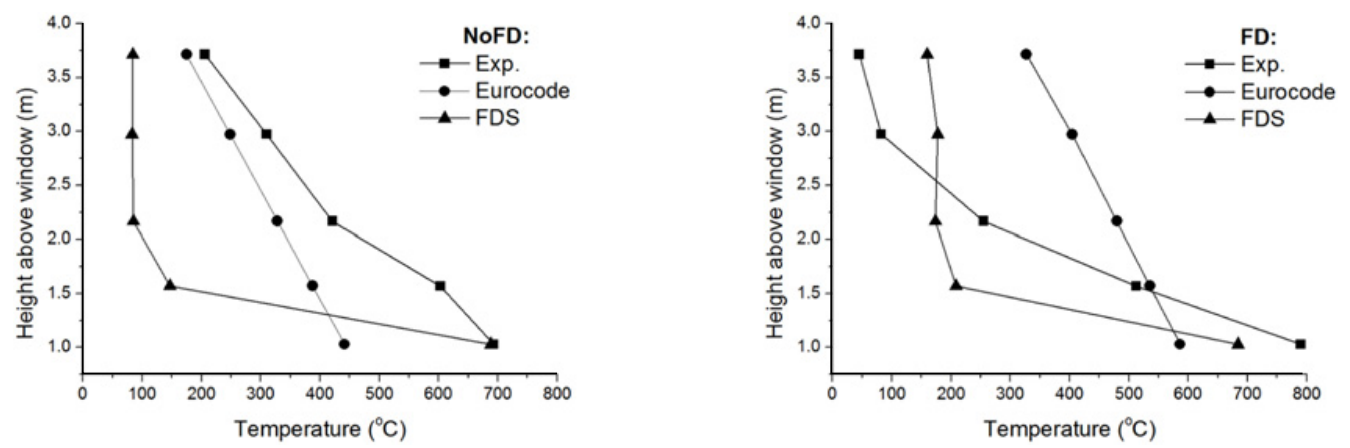

Figure 9. Centreline EVF temperatures in the NoFD (left) and FD (right) test case.

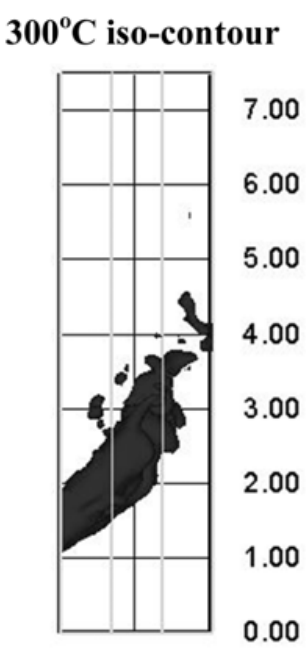

$2.001 .00 \quad 0.00$

\section{$540^{\circ} \mathrm{C}$ iso-contour}

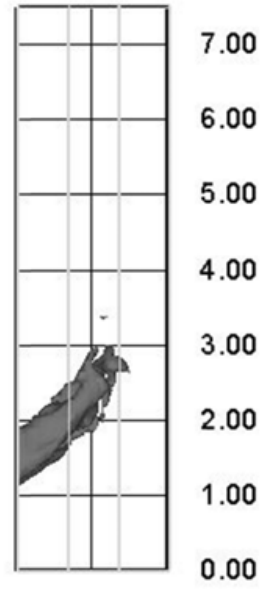

$2.001 .00 \quad 0.00$

\section{$300^{\circ} \mathrm{C}$ iso-contour}

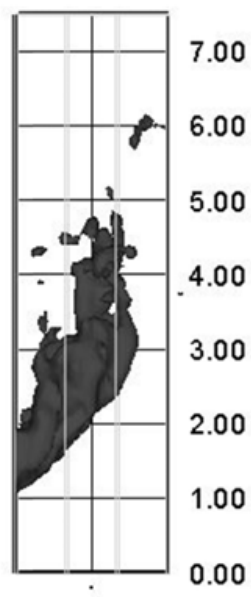

$2.001 .00 \quad 0.00$ $540^{\circ} \mathrm{C}$ iso-contour

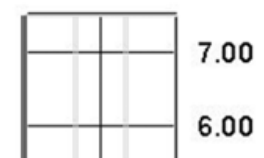

5.00

4.00

3.00

2.00

1.00

0.00

$2.001 .00 \quad 0.00$

Figure 10. Predictions of $300^{\circ} \mathrm{C}$ and $540^{\circ} \mathrm{C}$ iso-contours for the NoFD (left) and FD (right) test case.

(CEF) period. The CEF corresponds to the time period of the fully developed fire stage where EVF is consistently observed at the exterior of the fire compartment-façade configuration [18]. According to the experimental data, the CEF period for the NoFD and the FD test cases were observed at the time periods $945 \mathrm{~s}-1425 \mathrm{~s}$ and $1119 \mathrm{~s}-1399 \mathrm{~s}$ after fire initiation, respectively. CFD predictions of EVF centerline temperatures (Figure 9) indicate that good levels of qualitative agreement are observed in both the NoFD and FD test cases. CFD predictions outperform the Eurocode correlations in the FD case, whereas they significantly under-predict the measured temperatures in the NoFD case. Values obtained using the Eurocode correlations are on the safe side (over-prediction compared to measurements) in the FD case; however, the significant under-prediction of the experimental data in the NoFD case, especially close to the window, may represent a potential risk when used for building design purposes. It is evident that the under-ventilated fire NoFD conditions present a significant challenge for both CFD modeling and the Eurocode correlations.

\subsection{EVF Geometric characteristics}

The actual geometric boundaries of the EVF change dynamically; the most common approaches to determine the shape and location of the EVF are visual observation, photographic studies and 


\section{MATEC Web of Conferences}

Table 2. EVF geometric characteristics for the NoFD and FD test cases.

\begin{tabular}{ccccccc}
\hline \multirow{2}{*}{ Test case } & \multicolumn{2}{c}{$\begin{array}{c}\text { Maximum height above the top } \\
\text { of the window during CEF }(\mathrm{m})\end{array}$} & \multicolumn{4}{c}{$\begin{array}{c}\text { Maximum distance away from the façade } \\
\text { wall during CEF }(\mathrm{m})\end{array}$} \\
\cline { 2 - 7 } & $\begin{array}{c}\text { Experimental } \\
\text { Nowrocode }\end{array}$ & FDS & Experimental & Eurocode & FDS \\
\hline FD & $2.74-3.34$ & 1.37 & $1.0-2.0$ & $0.5-1.0$ & 0.5 & $1.0-1.5$ \\
FD & 2.03 & 1.1 & $1.5-2.5$ & $1-1.5$ & 1.7 & $\sim 1.5$ \\
\hline
\end{tabular}

high-speed cinematography. Difficulties in accurately determining the flame boundaries, especially in the intermittent flame region, render the definition the EVF's geometric boundaries a quite challenging task. Currently, no universally accepted level for the visible flame tip temperature exists for the intermittent flame region of open flames. Early research work on EVF from compartment fires [19] adopted the threshold temperature value of $540^{\circ} \mathrm{C}$, but more recent studies on visible flame tips of free burning cellulosic materials $([20,21])$ determined this threshold value to lie at a range between $300{ }^{\circ} \mathrm{C}$ and $600{ }^{\circ} \mathrm{C}$. In this context, CFD predictions of temperature iso-contours at the $300^{\circ} \mathrm{C}$ and $540{ }^{\circ} \mathrm{C}$ levels are depicted in Figure 10 in an attempt to define the geometric boundaries of the EVF. The presented computational data are averaged during the CEF period and both threshold values are used in order to compute the maximum height and width of the EVF. As expected, the FD case results in larger shape and higher height of the EVF compared to the NoFD case.

Measured and predicted geometric characteristics of the EVF for both test cases are presented in Table 2. CFD predictions and Eurocode correlations agree well with measurements of the maximum distance of the EVF from the façade; CFD simulations achieve a higher level of agreement in both the NoFD and FD cases. Both methodologies yield a conservative (over-prediction of the measured values) approximation of this quantity. However, the maximum height of the EVF from the top of the window is significantly under-predicted by both CFD and Eurocode methodologies; once more, a potential risk is present when Eurocode correlations are used for building design purposes.

\section{CONCLUSIONS}

The dynamic nature of EVF requires the use of advanced modeling methodologies, capable of describing the relevant physical phenomena in sufficient detail; the commonly used prescriptive methodologies are based on a phenomenological approach that exhibits certain limitations, especially when unusual structures are considered. CFD tools may provide significant assistance to the fire safety engineering analysis of EVF, by offering the opportunity to obtain an in-depth view of the spatial and temporal distribution of important physical parameters such as velocity, gas temperatures, wall temperatures etc. The ability of currently available CFD tools to adequately describe EVF is assessed, using measurements in a large-scale corridor-fire compartment-façade configuration exposed to realistic fire conditions. The obtained predictions are compared to available experimental data; good qualitative and, in certain cases, quantitative agreement is observed. The performance of the CFD tool is improved when FD conditions are considered. Measurements and CFD predictions are also compared to correlations used in the current Eurocode prescriptive methodology. The Eurocode correlations are found to be on the conservative side, especially when FD conditions are considered; however description of an under-ventilated NoFD fire compartment still poses significant challenges for both CFD tools and Eurocode correlations. Aiming to investigate the occurring phenomena, as well as to further evaluate the performance of both prescriptive and performance-based tools in accurately describing the EVF characteristics, an extended experimental and simulation campaign is planned, using a medium-scale fire compartment-façade configuration. 
$1^{\text {st }}$ International Seminar for Fire Safety of Facades, Paris (France), 2013

This study was financially supported by the "Fire-Facts" project in the frame of the ARISTEIA action (operational program "Education and Lifelong Learning") that is co-financed by Greece and the E.U.

\section{References}

[1] Eurocode 1: Actions on Structures, Part 1-2-General Actions-Actions on Structures Exposed to Fire, Brussels, 2002.

[2] Mammoser. J.H. and Battaglia F., "A computational study on the use of balconies to reduce flame spread in high-rise apartment fire", Fire Safety Journal, 39, 277-296, 2004.

[3] Meunders, A., Trettin, C., Wittbecker, F., "The capability of FDS to model flames and plumes emerging from compartment openings", Proceedings of the International Congress of Fire Computer Modelling, 457-470, Santander, Spain, 18-19 October, 2012.

[4] Satoh, K. And Kuwahara, K., "Numerical study of window-to-window propagation in high-rise building fires", Proceedings of the $3^{\text {rd }}$ International Symposium of Fire Safety Science, 355-364, Edinburg, UK, 8-12 July, 1991.

[5] Galea, E.R., Berhane, D. and Hoffmann, N.A., "CFD Analysis of Fire Plumes from windows with external protrusions in high rise buildings", Proceedings of the $6^{\text {th }}$ International INTERFLAM Conference, 307-319, Oxford, UK, 30 March - 1 April, 1993.

[6] Hwang, C.H., Lock, A., Bundy, M., Johnsson, E. and Ko, G.H., "Studies of fire characteristics in over- and underventilated full-scale compartments", Journal of Fire Sciences, 28, 459-486, 2010.

[7] Pierce, J.B.M. and Moss, J.B., "Smoke production, radiation heat transfer and fire growth in a liquid-fuelled compartment fire", Fire Safety Journal, 42, 310-320, 2007.

[8] Klopovic, S. and Turan, O.F., "A comprehensive study of externally venting flames, Part I: Experimental plume characteristics for through-draft and no-through-draft ventilation conditions and repeatability", Fire Safety Journal, 36, 99-133, 2001.

[9] Klopovic, S. and Turan, O.F., "A comprehensive study of externally venting flames, Part II: Plume envelope and center-line temperature comparisons, secondary fires, wind effects and smoke management system", Fire Safety Journal, 36, 135-172, 2001.

[10] Jahn, W., Rein, G., and Torero, J.L., "A posteriori modelling of the growth phase of Dalmarnock Fire test One", Building and Environment, 46, 2011, pp. 1065-1073.

[11] Lin, C.H., Ferng, Y.M. and Hsu, W.S., "Investigating the effect of computational grid sizes on the predicted characteristics of thermal radiation for a fire", Applied Thermal Engineering, 29, 2009, pp. 2243-2250.

[12] McGrattan, K.B., Floyd, J., Forney, G., Baum, H. and Hostikka, S., "In improved radiation and combustion routines for a large eddy simulation fire model", Proceedings of the $7^{\text {th }}$ International Symposium of Fire Safety Science, 827-838, Worcester, MA, USA, 15-19 June, 2002.

[13] Zhang, X., Yang M., Wang J. and He, J., "Effects of computational domain on numerical simulation of building fires", Journal of Fire Protection Engineering, 20, 225-251, 2010.

[14] Ariyanayagam, A. D. and Mahendran, M.,"Fire safety of buildings based on realistic fire timetemperature curves", Proceedings of the World Building Congress 2013, Brisbane Convention \& Exhibition Centre, Brisbane, Australia, 5-9 May 2013.

[15] Thomas, P.H. and Law M., "The projection of flames from burning buildings", Fire Research Station, Fire Research Note No921, Borehamwood, USA, 1972.

[16] Law, M. And O'Brien, T., "Fire safety of bare external structural steel", Construction Steel Research and Development Organisations, London, UK, 1989.

[17] Floyd, J. E., "Comparison of CFAST and FDS for fire simulation with the HDR T51 and T52 Tests", National Institute of Standards and Technology, NISTIR 6866, US, 2002.

[18] Klopovic, S. and Turan, O.F., "Flame venting externally during full-scale flashover fire: two sample ventilation cases", Fire Safety Journal, 31, 117-142, 1997. 


\section{MATEC Web of Conferences}

[19] Yokoi, S., "Study on the prevention of fire spread caused by hot upward current", Building Research Institute, Report No. 34, Japan, 1960.

[20] Inganson, H., "Two dimensional rack storage fires", Proceedings of the $4^{\text {th }}$ International Symposium on Fire Safety Sciences, 1209-1220, Ottawa, Canada, 13-17 July, 1994.

[21] Sullivan, A.L., Ellis, P.F. and Knight, I.K., "A review of radiant heat flux models used in bushfire applications", International Journal of Wildland Fire, 12, 101-110, 2003. 